\title{
NUMERICAL STUDY ON PILES PERFORMANCE IN SAND SLOPE STABILITY UNDER VARIABLE CONDITIONS
}

\author{
Yousry Mohamed Mowafy ${ }^{1}$, Ahmed Rushdy Towfeek ${ }^{2}$, Ahmed Kamal Mohamed ${ }^{2}$ \\ ${ }^{1}$ Faculty of Engineering, Al-Azhar University, Cairo, Egypt \\ ${ }^{2}$ Faculty of Engineering, Al-Azhar University, Qena, Egypt
}

\begin{abstract}
Sand - gravel (SG) soil stabilized by cement kiln dust (CKD) in mixture reinforced by Glass Fiber (GF) as new piles body properties are tried to present the needed parameters for simulating pile reinforced sand slope on Plaxis $2 \mathrm{D}$ program. A numerical investigation by the Finite Element Method (FEM) was simulated on Plaxis 2D by modelling sand slope supported by mentioned piles under strip footing loads. The Piles material was simulated as SG - 30\% CKD - 1\% GF mixture parameters. On the other hand, numerical investigation was analyzed to adopt the settlement (S) improvement limits, and to obtain the needed force which safes sand slope stability by decreasing of lateral displacement $(\delta)$ and $(\mathrm{S})$ to a desired value. It is clear that simulating sand slope with angle $\left(40^{\circ}\right)$ under pressure $\left(\mathrm{q}=280 \mathrm{kN} / \mathrm{m}^{2}\right)$ is more critical. Piles with mentioned conditions found a solution for slope with the critical angle $\left(40^{\circ}\right)$ stability by saving the value of safety factor (F.S > 1.5). General indexes refer to the importance of increasing piles embedded length in stable layers according to the mentioned pile dimentions ratio.
\end{abstract}

Keywords: Cement dust, Finite Element, Glass Fiber, Gravel, Reinforced Pile, Sand, Safety Factor, Slope Stability

\section{INTRODUCTION}

Improving soil properties is a result of finding methods for supporting soil under foundation loads. In literature studies, preparing of soil with composite material and testing soil modified by other materials or reinforcing are methods for improving some properties under foundation loads (e.g. [1], [2], [3], [4]; [5]; [6]). Slope stability is one of soil problems particularly with the case of sand soil. Estimation of the lateral force is an important point for the slope stability analysis.

Most of past researches also have attentions of soil slope problems and this can be the consequence of using reinforcing soil layers to improve some properties. Modelling of slope with piles (coupled slope) and without (uncoupled slope) was to show the piles efficiency in resisting slope failure, the limits of sand slope stability. Several numerical studies were conducted by the finite element method (FEM) and limit equilibrium method (LEM) on several computer programs. Lateral load behavior of single piles in cohesion or cohesionless soils was studied, for different Length/Diameter (L/D) ratio by changing the diameter and length of pile. Increasing of pile diameter increases lateral load capacity for the same length, and this was due to the increase in surface area, [7]. As evidenced by Figure (1), the sliding soil mass above the failure surface is assumed to be reinforced by the placed piles that resist soil movements and transfer pressures to the more stable layers on pile embedded length [8]. 


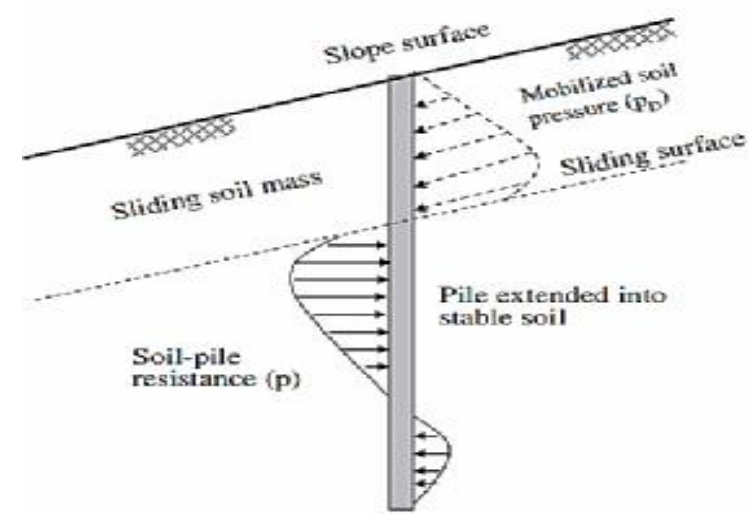

Fig 1: Force router by displaced soil mass above the sliding surface (After Mugah D. et al [8])

Increasing the piles diameter and spacing ratio between the piles increases the resistance force [9]. Ito and Matsui's [10] approach gives a linear solution for estimating the lateral force. The theories of plastic deformation and plastic flow have been applied. The deformation was considered in the out - of - plan. The lateral force $(\mathrm{P})$ acts on the piles as an interaction between the piles and soil.

\section{MATERIAL PROPERTIES}

The laboratory work consisted of testing the used material mixture by obtaining compressive strength parameters as prescribed in [11], [12]. Piles material was simulated as SG - 30\% CKD - 1\% GF with the shown properties in Table (1).

Table 1: Numerical model Properties for piles

\begin{tabular}{||c|c||c||c||c||}
\hline $\begin{array}{c}\text { module of elasticity } \\
\mathrm{E}\left(\mathrm{kN} / \mathrm{m}^{2}\right)\end{array}$ & $\begin{array}{c}\mathrm{C} \\
\left(\mathrm{kN} / \mathrm{m}^{2}\right)\end{array}$ & $\phi$ & $\begin{array}{c}\text { unit weight } \\
\left(\mathrm{kN} / \mathrm{m}^{3}\right)\end{array}$ & $\begin{array}{c}\text { Slope angle } \\
\alpha\end{array}$ \\
\hline \hline $1.73 * 10^{7}$ & 7661 & 0 & 20.5 & $33.7^{\circ}$ \\
\hline
\end{tabular}

\section{NUMERICAL MODEL}

This part presents the analyzed sand slope model with mentioned Boundary Conditions and the mixture columns under strip footing located in fixed location on sand slope crest.

\subsection{Soil Boundary Conditions}

The vertical boundaries of the model were constrained horizontally, and the bottom boundary was constrained in both horizontal and vertical directions. It was important to avoid direct influence on the boundary conditions. So, starting with enough wide dimensions was intentioned because the influence zone of the soil movements wasn't known yet. Therefore, it was necessary to make a model with wide boundaries. The model dimensions of sand slope under strip footing can be seen in Figure (2). 


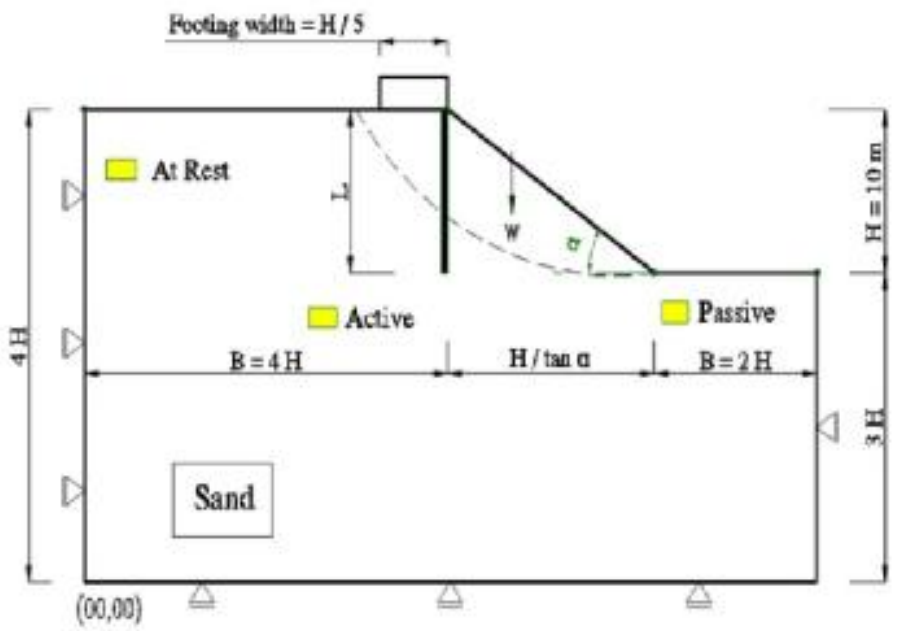

Fig 2: The model of Sand slope with variable parameters

Modelling plate element in Plaxis 2D is the used object to selecting piles as slender structures like plates, soldier piles, secant piles. So, axisymmetric model is the way to simulate the circular elements. Modelling as plane strain deals with relatively uniform loaded cross-section in the $\mathrm{z}$ - direction, see Figure (3) to comparison between axisymmetric and plane strain model in Plaxis 2D (V.8) [13].

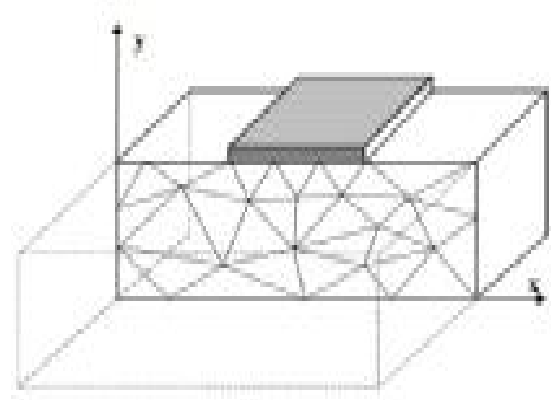

Plane strain

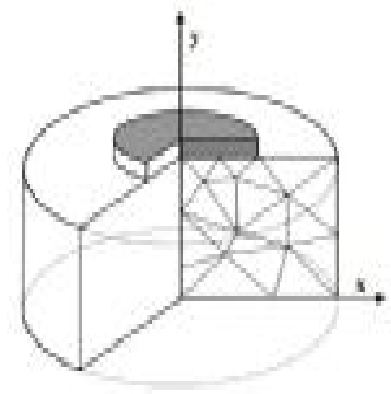

Axisymmetric

Fig 3: Comparison between plane strain and axisymmetric model

\subsection{Piles Boundary Conditions}

Choosing piles dimensions was according to length/diameter ratio $\left(\mathrm{L}_{\text {pile }} / \mathrm{D}\right)$, and according to piles spacing in the out - of - plan to piles diameter also $\left(\mathrm{L}_{\mathrm{s}} / \mathrm{D}\right)$.

Because of the sand cohesionless state, it was intentioned to apply Plaxis $2 D$ [13] assumptions in using the case of simulating piles row in out- of - plan as wall behavior $\left(1=\mathrm{L}_{\mathrm{s}} / \mathrm{D}<1.5\right)$, see Figure (4).

$$
\text { L/D }=1
$$

Fig 4: Dependency of behaviour according to L/ D ratio (Plaxis 2D) 
The equivalent thickness $\left(\mathrm{d}_{\mathrm{eq}}\right)$ was determined by Plaxis by equation no. (1), [14].

Table (2) shows the required parameters in Plaxis 2D to specify piles as plate in sand slope geometry.

$$
d_{e q}=\sqrt{12 \frac{E I}{E A}}
$$

Table 2: The piles specified parameters in Plaxis 2D model

\begin{tabular}{|c|c|c|c|c|c|c|c|}
\hline $\begin{array}{l}\text { Mixture } \\
\text { pile } \\
\text { Code }\end{array}$ & $\begin{array}{c}\text { Piles } \\
\left(\mathrm{L}_{\mathrm{s}} / \mathrm{D}\right) \\
\text { ratio }\end{array}$ & $\begin{array}{c}\text { Piles } \\
\left(\mathrm{L}_{\text {pile }} / \mathrm{D}\right) \\
\text { ratio }\end{array}$ & $\begin{array}{c}\text { Pile } \\
\text { diameter } \\
D(m)\end{array}$ & $\begin{array}{c}\text { Axial } \\
\text { Stiffness } \\
(\mathrm{EA}) \\
\mathrm{kN} / \mathrm{m}\end{array}$ & $\begin{array}{c}\text { Flexural } \\
\text { Rigidity (EI) } \\
\text { kN.m²/m }\end{array}$ & $\begin{array}{c}\text { Equivalent } \\
\text { thickness } \\
\left(d_{\mathrm{eq}}\right) \mathrm{m}\end{array}$ & $\begin{array}{c}\text { pile } \\
\text { Weight } \\
(\mathrm{w}) \\
\mathrm{kN} / \mathrm{m} / \mathrm{m}\end{array}$ \\
\hline MP1 & \multirow{6}{*}{$t$} & 15 & \multirow{3}{*}{1} & \multirow{3}{*}{$13.6 \times 10^{6}$} & \multirow{3}{*}{$8.65 \times 10^{5}$} & \multirow{3}{*}{0.874} & \multirow{3}{*}{16} \\
\hline MP2 & & 20 & & & & & \\
\hline MP3 & & 25 & & & & & \\
\hline MP4 & & 30 & \multirow{3}{*}{0.5} & \multirow{3}{*}{$3.4 \times 10^{6}$} & \multirow{3}{*}{$5.4 \times 10^{4}$} & \multirow{3}{*}{0.437} & \multirow{3}{*}{4} \\
\hline MP5 & & 40 & & & & & \\
\hline MP6 & & 50 & & & & & \\
\hline
\end{tabular}

\section{RESEARCH OBJECTIVES}

The current research objectives were to present

a) The needed force which safes sand slope stability with decreasing (S) to a desired value,

b) The settlement improvement limits,

c) Lateral pressure capacity by supporting with mentioned piles,

d) Finding a solution for implementing slope with the critical angle $\left(40^{\circ}\right)$.

\section{Numerical Verification}

Numerical analysis in current study was firstly on sand slope without stabilization by two methods. The first part of the solution, GEO5 2017 as slope stability program was used with choosing factor of safety $(\mathbf{F . S} \geq 1.5)$ in analysis setting. On GEO5 program, simulating the sand slope was by select "Bishop" as the analysis method. This part is to present the expected critical stress which cause slope failure by decreasing (F.S) about 1.5. The second part was on Plaxis 2D by Finite Element Method (FEM) to present some of slope behavior under footing loads.

\subsubsection{Unsupported sand slope}

This to show the improvement limits with supporting by piles. The required shown improvement could be in more stability under bigger stresses with smaller settlement, and more resisting to lateral pressures.

\subsubsection{Sand Slope stability - Limit Equilibrium Method (LEM)}

GEO5 2017 as slope stability program was used with choosing factor of safety (F.S $\geq 1.5)$ in analysis setting. Using GEO5 2017 program was to present the failure case under the effect of defined stress with gradient of $(1 \mathrm{~V}: 1.5 \mathrm{H})$ which represents slope angle of $\left(\alpha=33.7^{\circ}\right)$ without supporting. The study was conducted for constant slope height $(\mathrm{H})=10 \mathrm{~m}$. Optimization is to let the program finding the worst position of slip surface (critical with the lowest safety factor). The program performed the actual verification by clicking on "Analyze". With slope angle of $\left(\alpha=33.7^{\circ}\right)$ under uniform distributed stress 
$\left(\sigma=200 \mathrm{kN} / \mathrm{m}^{2}\right)$, and by choosing circular slip surface, GEO5 optimization calculated $(\mathbf{F} . \mathbf{S}=1.5)$ and considered that slope stability "NOT ACCEPTABLE", see Table (3).

Table 3: Values of F.S for different slope angle under the same load

\begin{tabular}{|c||c||c||c|c||}
\hline$\phi$ & $\mathrm{C}\left(\mathrm{kN} / \mathrm{m}^{2}\right)$ & slope angle $\alpha$ & $\sigma\left(\mathrm{kN} / \mathrm{m}^{2}\right)$ & $\mathrm{F} . \mathrm{S}$ \\
\hline \multirow{2}{*}{$41.5^{\circ}$} & 9 & $33.7^{\circ}$ & 200 & 1.5 \\
\cline { 3 - 5 } & & & 280 & 1.35 \\
\hline
\end{tabular}

\subsubsection{Sand slope stability - Finite Element Method (FEM)}

The theory of simulation may be developed by dimensional analysis. The failure of slope occurs when the applied shear stress exceeds the soil shear strength along the plane of failure. In Plaxis, FEM is the used method for calculations. The same obtained load by GEO5 was the parameter ultimate load in Plaxis geometry model to be defined with angle $\left(33.7^{\circ}\right)$.

\subsubsection{Ultimate bearing load $\left(q_{u}\right)$ versus Ultimate settlement $\left(S_{u}\right)$}

Under modelling strip footing by applying the ultimate load $\left(\mathrm{q}_{u}=280 \mathrm{KN} / \mathrm{m}^{2}\right)$ on slope with indicated slopes angle $\left(\alpha=33.7^{\circ}\right)$, high value of settlement was resulted $\left(S_{u}=125.5 \mathrm{~mm}\right)$. Under pressure $(q=200$ $\mathrm{KN} / \mathrm{m})$, settlement decreased to the half $(\mathrm{S}=63.39 \mathrm{~mm})$.

\subsection{Slope behavior according to piles (Lpile / D) ratio}

Increasing of $\left(\mathrm{L}_{\text {pile }} / \mathrm{D}\right)$ ratio (MP1, MP2, and MP3) and the effect of decreasing diameter (MP4, MP5, and MP6) which is accompanied by more increasing of $\left(\mathrm{L}_{\text {pile }} / \mathrm{D}\right)$ ratio with the same constant used case of wall behavior ( $\mathrm{L} / \mathrm{D}=1)$ which have been studied.

\subsubsection{Ultimate bearing load $\left(q_{u}\right)$ versus Ultimate settlement $\left(S_{u}\right)$}

Under the ultimate load $\left(\mathrm{q}_{\mathrm{u}}=280 \mathrm{kN} / \mathrm{m}^{2}\right)$, results introduced a significant decrease in vertical settlement values. Figure (5) evidence a comparison between the ultimate vertical load - Settlement relationships for slope reinforced with mentioned piles and without. The piles MP3, MP6 where $\left(\mathrm{L}_{\text {pile }} / \mathrm{D}=25\right),\left(\mathrm{L}_{\text {pile }} / \mathrm{D}=\right.$ 50) respectively are the best cases with more decreasing in settlement. General indexes refer to the importance of increasing embedded piles length in stable layers.

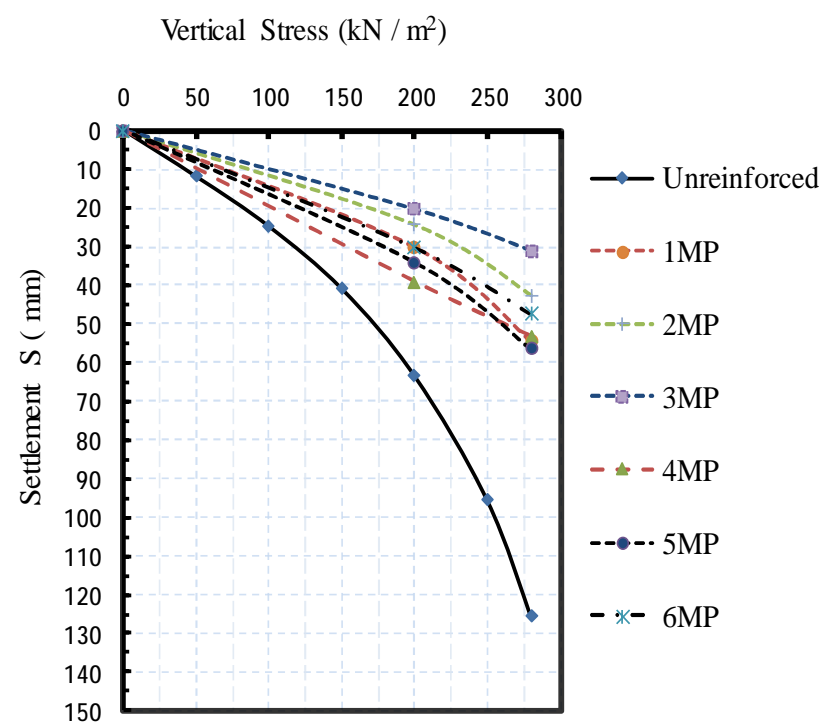

Fig 5: Vertical stress - Settlement relationship for piles reinforced sand slope 


\subsubsection{Lateral displacement versus lateral pressure}

Lateral displacement consequence from lateral pressure which is a result of vertical stress. So under applying footing stress on sand slope, lateral displacement has been calculated. As in Figure (6), an improvement in slope stability has been observed by supporting with mentioned piles.

By supporting the slope under the same ultimate stress $\left(q_{u}=280 \mathrm{KN} / \mathrm{m}^{2}\right)$, results introduce a significant decrease in lateral movement values which refer to more avoiding to slope horizontal movement with piles.

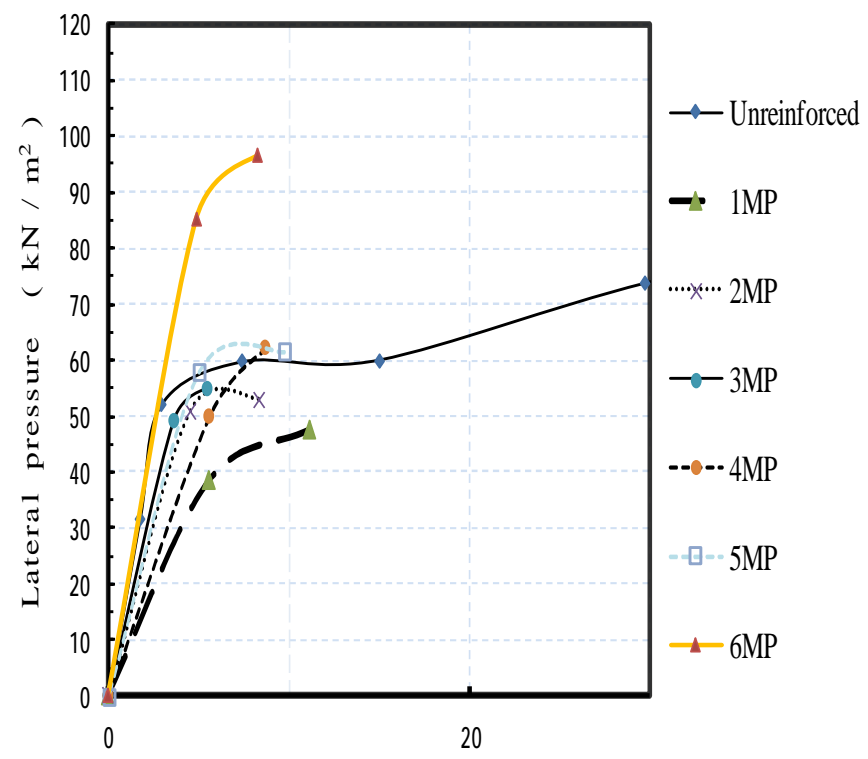

Lateral displacement $\delta(\mathrm{mm})$

Fig 6: Lateral pressure - Lateral displacement according to piles reinforced slope

\subsubsection{Effect of Slope Angle variation on F.S}

Modelling slope with angle $\left(40^{\circ}\right)$ and by trying to introduce the slope behavior under pressure $\left(\mathrm{q}_{u}=\right.$ $280 \mathrm{KN} / \mathrm{m}^{2}$ ), it was investigated that Soil body Collapses in case of unsupported slope and the F.S values decreased about slope with angle $\left(33.7^{\circ}\right)$. By Modelling the piles by mentioned boundary conditions in slope with angle $\left(40^{\circ}\right)$, the factor of safety values are still (F.S $>1.5$ ) although slope angle variation is to the critical one. The results introduce more confidence as shown in Table (4).

Table 4: Reinforced slope stability limits with variable angles $\left(q_{u}=280 \mathrm{kN} / \mathrm{m}^{2}\right)$

\begin{tabular}{|c|c|c|c|c|c|c|c|c|}
\hline \multirow{3}{*}{$\begin{array}{c}\mathrm{q}_{\mathrm{u}} \\
\left(\mathrm{kN} / \mathrm{m}^{2}\right)\end{array}$} & \multirow{3}{*}{$\alpha$} & Unreinforced slope & & & reinfor & ed slo & & \\
\hline & & \multirow{2}{*}{ F.S } & \multicolumn{6}{|c|}{ F.S } \\
\hline & & & MP1 & MP2 & MP3 & MP4 & MP5 & MP6 \\
\hline \multirow{2}{*}{280} & $33.7^{\circ}$ & 1.04 & 1.47 & 1.66 & 1.86 & 1.47 & 1.59 & 1.64 \\
\hline & $40^{\circ}$ & Soil body collapses & 1.4 & 1.59 & 1.62 & 1.4 & 1.52 & 1.6 \\
\hline
\end{tabular}




\section{NCLUSIONS}

1)Useful results were adopted by using $\mathrm{SG}-30 \% \mathrm{CKD}-1 \% \mathrm{GF}$ as new piles material in retaining sand slopes under strip footing.

2)Modelling sand slope geometry supported by mentioned piles as plane strain model is suitable choice in Plaxis 2D.

3) The preferred Piles spacing in the (out - of - plan) to piles diameter ratio can be considered as wall behavior $\left(1=\mathrm{L}_{\mathrm{s}} / \mathrm{D}<1.5\right)$ because of sand cohesionless.

4)General indexes refer to the importance of inreasing embedded piles length in the stable layers according to mentioned $\left(\mathrm{L}_{\text {pile }} / \mathrm{D}\right)$ ratio.

5)According to unsupported slope with angle (33.7 ${ }^{\circ}$ ), the ultimate pressure can be considered $\left(\mathrm{q}_{\mathrm{u}}=95 \mathrm{KN} / \mathrm{m}^{2}\right)$ and the permissible ultimate settlement is $(23.5 \mathrm{~mm})$.

\section{REFERENCES}

[1] Al-Refeai, A. A. Al-Karni "Experimental study on the utilization of cement kiln dust for modification" J. King Soud University, Eng. Sci., Vol. 11, No. 2, pp. 217-232, K.S.A., 1999.

[2] Miller G. A., Azad Sh. "Influence of soil type on stabilization with cement kiln dust" Construction and Building Materials, J. Elsevier, Construction and Building Materials 14, pp. 8997, 2000.

[3] Toufigh V. "Experimental and analytical studies of Geo-Composite applications in soil

Reinforcement "Ph.D. dissertation, Dept civil eng. and eng. mechanics, Arizona Univ., the Graduate College.

[4] Albusoda B. S., Salem L. A. Kh. "Stabilization of Dune Sand by Using Cement Kiln Dust (CKD)"

J. Earth Sciences and Geotechnical Engineering, vol. 2, no. 1, pp. 131-143, 2012.

[5] Kumar B., Puri N. "Stabilization of weak pavement Subgrades using cement kiln dust" International J. Civil Engineering and Technology, IJCIET, Vol. 4, No. 1, pp. 26-37, 2013.

[6] Consoli N. C., Montardo J. P., Donato M., Prietto P. D. M." Effect of material properties on the behavior of sand-cement-fiber composites", Ground Improvement, Vol. 8, No. 2, PP. 77-90, 2004.

[7] Murugan M., Natarajan C., Muthukkumaran K., "Behavior of laterally loaded piles in cohesionless soils", International J. Earth Sciences and Engineering, ISSN 0974-5904, Vol. 04, No 06 SPL, pp. $104-106,2011$.

[8] Mujah D., Ahmad F., Hazarika H., Watanabe N. "The Design Method of Slope Stabilizing Piles: A Review", International J. Current Engineering and Technology, Vol. 3, No. 2, PP. 224-229, 2013.

[9] Poulos, H. G., "Design of reinforcing piles to increase slope stability", Geotechnical Engineering, Vol. 32 (5), pp. $808-818,1995$.

[10] Ito T, Matsui T "Methods to Estimate Lateral Force Acting on Stabilizing Piles", Soils Found. Vol. 15 (4), PP. 43-59, 1975.

[11] Mowafy Y. M., Towfeek A. R., Kamal A. M. 'Effect of Adding Glass Fiber on Compaction Properties of Sand - Cement Kiln Dust Mixtures" J. Saussurea, Vol. 6 (4), PP. 314 - 326, 2016.

[12] Mowafy Y. M., Towfeek A. R., Kamal A. M. 'Effect of Glass Fiber on Sand - Gravel soil mixture stabilized by cement dust", in Proceedings of the ICASGE'17, International Conference on Advances in Structural and Geotechnical Engineering, Hurghada, Egypt 2017, GEO-28.

[13] Plaxis 2D (V.8) "Reference manual", 2002.

[14] Sobhey M., El-Sawwaf M., Shahien M., Farouk A. "Lateral pressure developed on piles in clay slopes: Numerical study" in Proceedings of the ICASGE'17, International Conference on Advances in Structural and Geotechnical Engineering, Hurghada, Egypt 2017, GEO-11. 